\title{
Examining the Effects of Challenges Faced in Green Construction on Project Outcomes: A Chinese Perspective
}

\author{
Mohammed Shareef M. S. Hasan
}

\begin{abstract}
This study aims to investigate the common challenges that project managers encounter while managing green building construction projects and their impact on project success. Furthermore, the study aims to examine the mediating effect of project performance in the relationship between project management challenges related to green construction and their success. This paper seeks to contribute to the green construction in China. In total 500 questionnaires were distributed, and 376 completed survey questionnaires were received. Structural equation modelling (SEM) using AMOS was conducted to check various proposed relationships. The results reveal that Challenge 2 and Challenge 5 are insignificant and have no impact on project success, whereas Challenges 1, 3 and 4 are found to be the predictors of project success. No mediation effect of project performance is found between Challenges 1 and 5 and project success. However, a partial mediation effect is found between Challenge 1 and project success.
\end{abstract}

Index Terms-Green buildings, project success, project performance, challenges, SEM.

\section{INTRODUCTION}

Better business efficiency in the building industry can play a significant role in future development and the sustainability of development. Generally, in Asia the demand for energy in the construction and design sector is growing rapidly along with the economic growth [1], [2]. The literature contains a number of studies related to the social benefits of green buildings (GB). GB projects are subject to uncertainties about project deliverables; therefore, they require contingencies in project budgets [3].

The construction industry is subject to many diverse problems and requirements [4].

Many countries are now focusing on improving the performance of the construction industry as part of their socioeconomic development at various levels. The construction industry, due to its complexity and difficulty, faces problems and challenges throughout the world. These issues are dominant in developing countries, as these countries face a lack in terms of resources, socioeconomic issues, an inability to deal with critical situations and organizational weaknesses.

China is facing green construction challenges, as the population is continuing to boom along with its economy and people are moving to cities, stimulating an increase in urbanization and development [5]. Today, 51\% of China's

Manuscript received June 12, 2016; revised October 27, 2016.

Mohammed Shareef M. S. Hasan is with School of Civil Engineering and Mechanics, Huazhong University of Science and Technology, Wuhan 430074, Hubei, China (e-mail: shareef977@yahoo.com). population lives in urban areas. Between 1990 and 2005, the population of China's urban centres doubled. This growing urban population has spurred on such a significant increase in development that, by the end of $2006,65 \%$ of China's urban buildings were constructed within a 10-year span. In 2009 the McKinsey Global Institute estimated that China would build between 20,000 and 50,000 buildings of more than 30 floors by 2025 [6], [7]. However, with the population growth in China and the construction progress, the country is facing challenges in this sector, particularly green construction challenges, which are encountered in project management, affecting the project success and project outcomes in the construction sector.

In the construction industry, effective project management is crucial due to the nature of the industry [8], and the identification of effective approaches can lead to project success [9]. The success of building projects heavily depends on the project management methods, philosophy, techniques, procedures and processes and different tools. Additionally, the capability of the project manager $(\mathrm{PM})$ is one of the most important elements for the success of construction building projects [10], [11]. A construction PM has to consider everything to prevent failure in any step of the project. However, in most cases undesirable challenges arise in project implementation.

Moreover, the job of project manager is diversifying due to the changing nature of the construction industry, technological development and information technology. Project managers also face different challenges related to climate change, environmental policies and sustainability issues. They need skills to face these challenges and issues [12]. With the increasing global pressure for environmental protection and sustainability, many construction companies are now thinking about green projects. Companies are now focusing on more sustainable and environment-friendly construction, and that is why they are now carrying out green construction projects and design [13].

Key gap persist in existing knowledge. Although there is much debate about the likely outcomes of green construction, surprisingly few empirical studies have examined the effects of challenges faced in green construction on projects outcomes. Thus, project managers need to identify the challenges being faced by the green construction.

The role of project managers is changing completely due to critical issues that were not relevant in traditional project building [14]. Green construction is the top priority in the construction sector, and project managers have to deal with the challenges of green construction to complete projects successfully. Hence, the purpose of this study is to investigate the effects of green construction challenges on 
project success and outcomes in China.

\section{Literature REVIEW}

\section{A. Concept of Green Building}

The concept of green building (GB) was introduced by China's Government in 2004 with the platform of "EnergySaving and Land-Saving Residential Building". GB projects are categorized as energy-saving, land-saving and materialsaving projects. These are defined by the Chinese national standard, the Evaluation Standard for Green Building [15].

\section{B. Green Building Design}

Green building designs are more complex than typical conventional building designs, because it is commonly necessary for the design team to evaluate alternative materials and systems [16]. In conventional building projects, the simple and general planned designs are used for project process regarding what the building should look like generally [17]. However, a more up-to-date process is used from the beginning of green projects because of the fact that green buildings have many unique designs, integration and features that are not generally present in conventional projects [18], [19].

\section{Challenges in Green Construction Projects}

Based on previous studies, different skills and challenges related to project management in green building projects are found. These challenges are presented below:

\section{1) Higher costs for green construction practices and materials}

GB projects are subject to higher costs than conventional building projects. [20] stated that the cost of green building projects is $2 \%$ to $25 \%$ higher than that of conventional projects. Green projects are costly due to the presence of complexities in building design and the modelling of green practices to integrate into the projects [21]. The use of green technologies and green materials is the main cause of the increased cost of these projects [22].

The cost of materials in green projects is about $4 \%$ higher than that in conventional projects, and a significant contribution is made by the cost of green board, which is 10 times higher than that of the ordinary board used in conventional projects [21]. This increased cost of green projects directly affects the performance of project managers as they have to manage and deliver the project within the budget constraint [13], [18], [23].

\section{2) Technical difficulty during the construction process}

The project manager is responsible for implementing the project plan by assigning activities and authority to deliver project outcomes [23]. Green constructions require complex techniques and building designs [21]. The project manager's performance can be adversely affected if he or she fails to address these complexities. [20] highlighted that technical difficulties and complexities are the main challenges of green projects faced by project managers. Similarly, these designs are more complicated and complex due to the presence of complex materials and systems than conventional buildings [18].

\section{3) Risk due to different contract forms of project delivery}

The success of the development and implementation of green building design heavily depends on the type of contract selected for the project deliverables [20]. The type of contract used in green projects must incorporate the details of a fully integrated green design. If the design is locked prior to developing the green design fully, huge problems will arise in its implementation. In green projects numbers of changes are required at different stages, leading to their higher cost [18].

\section{4) Lengthy approval process for new green technologies} and recycled materials

According to the environment of the market, the planning process of green projects can be prolonged due to the approval process of new green technologies and materials [20]. As shown by the survey reports of [21] and [24], green design projects are expected to require additional time for approval than conventional designs. This additional and delayed time is a challenge for project managers in developing the schedule for the project and making payments to dealers and suppliers [18], [23].

\section{5) Unfamiliarity with green technologies}

Previous studies have documented certain obstacles and issues for design developers, contractors and clients. [24] identified that there are two main obstacles, insufficient knowledge and unfamiliarity with the design, material and systems. [20] pointed out that, compared with conventional technologies, green technologies are more complex and different. The same findings were suggested by [21]. The author suggests that the project manager is responsible for delivering the project within the required standards and performance measures as determined by the clients [23], and if the project manager is unfamiliar with the green technologies and does not have sufficient knowledge, it may affect his performance outcome [18].

\section{Project Performance}

Ref. [22], [25] estimated a hierarchical structural equation model to make clear comparisons. Exhibiting the unique characteristics of pharmaceutical construction projects regarding delivery, the project cost, timetable and performance metrics were produced. The further studies by [26], [27] showed that different stakeholders can gauge and assess the performance of projects effectively using the given metrics.

Ref. [28] assessed the association between the project factors and the performance of a project. Their study indicated the causal association among several project factors and five performance indicators: "reward ratio", "unit cost", "progress growth", "cost increases" and "speed of completion".

\section{E. Project Success}

During the actual execution of any project, several measurements, such as the environmental impact and the satisfaction of the clients regarding quality, cost and time, may be carried out [29].

The classical indicators used for gauging project success are the cost progress, safety and progress [30]. As far as the project cost and project progress success is concerned, a 
project can be considered to be successful in the case that the actual cost is lower than the forecasted cost and the actual progress is accelerated more than anticipated; otherwise, it may be considered to be a failure.

\section{RESEARCH Methodology}

To meet the research objectives, a comprehensive literature search was conducted. The review of the previous work aimed to understand the impact of the challenges faced in green construction on project outcomes. After reviewing the literature, the challenges were identified as the independent variable, whereas the project success and project outcome were set as dependent variables. Their relation is tested using structural equation modelling (SEM) by AMOS. A closed-ended question was prepared to collect primary data regarding the challenges of green construction, project performance and project success.

To collect the empirical data, a questionnaire was sent to a sample of green construction managers. Only green construction managers participated in this study, because they have experience and knowledge regarding green construction.

The purposive sampling technique is employed in this study. The use of purposive sampling in this study is parallel to previous studies, the logical reasoning being to obtain in-depth and meaningful information by purposefully selecting the most suitable sample. To ensure that the sample of this study consisted of the correct respondents, only construction managers who possess knowledge or experience in green construction were selected.

The first part of the questionnaire included information regarding the respondents' demographic factors. The following part listed the challenges faced by the managers in dealing with green construction projects. The questions to rate the effectiveness of the challenges used a five-point scale from not relevant at all to most relevant. The last part consisted of questions regarding project success and project performance using an interval scale with five points from strongly disagree to strongly agree. A total of 500 questionnaires were distributed to collect responses; however, 376 completed questionnaires were received, achieving a response rate of $75 \%$. The numbers of items used to measure each construct are shown in Table I.

TABLE I: LIST OF CONSTRUCTS AND THE NUMBER OF ITEMS INCLUDED

\begin{tabular}{llll}
\hline CONSTRUCTS & LABEL & TYPE & ITEMS \\
\hline Higher costs & Challenge 1 & IV & 3 \\
Technical difficulty & Challenge 2 & IV & 4 \\
$\begin{array}{l}\text { Risk due to different contract } \\
\text { forms }\end{array}$ & Challenge 3 & IV & 4 \\
Lengthy approval & Challenge 4 & IV & 3 \\
Unfamiliarity with Green & Challenge 5 & IV & 4 \\
Technology & & & \\
Project Performance & PP & MV & 3 \\
Project Success & PS & DV & 3 \\
\hline
\end{tabular}

Note: IV: Independent variable. Items refer to number of questions for each variable. MV means mediation variable. DV means dependent variable.

\section{A. Hypotheses}

H1a: Higher cost is a predictor of project success.
H1b: Project performance mediates the relationship between higher cost and project success.

$\mathrm{H} 2 \mathrm{a}$ : Technical cost is a predictor of project success.

$\mathrm{H} 3 \mathrm{a}$ : Risk due to different contract forms is a predictor of project success.

H3b: Project performance mediates the relationship between risk due to different contract forms and project success.

H4a: Lengthy approval is a predictor of project success.

$\mathrm{H} 4 \mathrm{~b}$ : Project performance mediates the relationship between lengthy approval and project success.

H5a: Unfamiliarity with green technology is a predictor of project success.

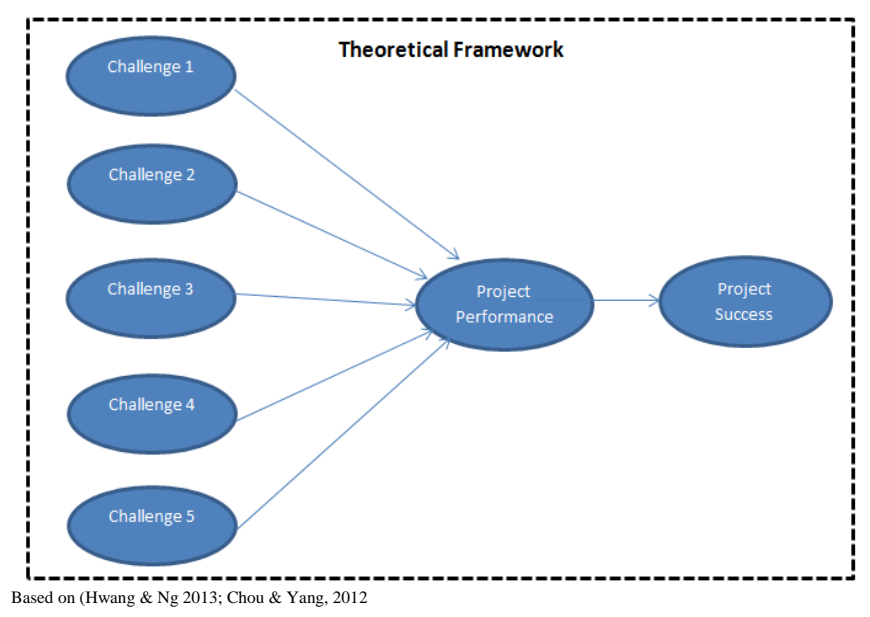

Fig. 1. Theoretical framework.

\section{RESUlTS AND DISCUSSION}

\section{A. Validity and Reliability}

Measurement models were designed to assess the convergent validity. Table 2 provides a summary of the validity and reliability. A model was prepared for multidimensional constructs (CH1, CH2, CH3, CH4, CH5, PP and PS); items with a loading less than 0.50 were deleted [31]. Convergent validity was established through standardized estimates (standard regression weight [SRW] > 0.5 ) and average variance extracted (AVE > 0.05). To check the internal consistency, Cronbach's alpha was used, as it is an indicator of the reliability of the construct [32]. In this study the values of alpha for all the constructs are more than 0.80 . The composite reliability values, which depict the degree to which the construct indicators indicate the latent construct, exceed the recommended value of 0.80 for all the constructs. The composite reliability for all the constructs is above 0.80 except for the variable "project success (PS)". However, it is at an acceptable level and may be used for further analysis. Hence, the scale reliability using Cronbach's alpha indicates sufficient reliability and the construct composite reliability is considerably above the acceptable level.

The assessment of discriminant validity enables researchers to determine how one construct differs from the others. The value of discriminant validity can be determined when the AVE square root of two constructs and their correlations are compared. Discriminant validity was tested for the model (Table III). The stringent approach to 
ascertain the discriminant validity of the model is to compare the square root of the AVE value of each construct with the squared inter-construct correlations related to that construct. To confirm discriminant validity, these AVE estimates should be greater than the inter-construct squared correlations. Table III illustrates that the AVE values (in bold diagonally) in all the constructs are greater than their squared correlations. This indicates that the constructs have appropriate discriminant validity.

\begin{tabular}{lllll}
\multicolumn{5}{c}{ TABLE II: VALIDITY AND RELIABILITY OF SCALES } \\
\hline & $\begin{array}{l}\text { Standard } \\
\text { Estimates }\end{array}$ & AVE & Alpha & CR \\
\hline $\mathrm{CH} 1$ & & 0.61014 & 0.82 & 0.823623203 \\
$\mathrm{CH} 1 \mathrm{a}$ & 0.853 & & & \\
$\mathrm{CH} 1 \mathrm{~b}$ & 0.771 & & & \\
$\mathrm{CH} 1 \mathrm{c}$ & 0.713 & & & \\
\hline $\mathrm{CH} 2$ & & 0.666374 & 0.88 & 0.888621304 \\
$\mathrm{CH} 2 \mathrm{a}$ & 0.814 & & & \\
$\mathrm{CH} 2 \mathrm{~b}$ & 0.86 & & & \\
$\mathrm{CH} 2 \mathrm{c}$ & 0.774 & & & \\
$\mathrm{CH} 2 \mathrm{~d}$ & 0.815 & & & \\
\hline $\mathrm{CH} 3$ & & 0.647949 & 0.87 & 0.87950294 \\
$\mathrm{CH} 3 \mathrm{a}$ & 0.707 & & & \\
$\mathrm{CH} 3 \mathrm{~b}$ & 0.77 & & & \\
$\mathrm{CH} 3 \mathrm{c}$ & 0.911 & & & \\
$\mathrm{CH} 3 \mathrm{~d}$ & 0.818 & & & \\
\hline $\mathrm{CH} 4$ & & 0.795598 & 0.92 & 0.921068315 \\
$\mathrm{CH} 4 \mathrm{a}$ & 0.862 & & & \\
$\mathrm{CH} 4 \mathrm{~b}$ & 0.895 & & & \\
$\mathrm{CH} 4 \mathrm{c}$ & 0.918 & & & \\
\hline
\end{tabular}

\begin{tabular}{lllll}
\hline CH5 & & 0.661773 & 0.88 & 0.885897919 \\
CH5a & 0.915 & & & \\
CH5b & 0.786 & & & \\
CH5c & 0.826 & & & \\
CH5d & 0.714 & & & \\
\hline PP & & 0.710339 & 0.87 & 0.879631836 \\
PP1 & 0.744 & & & \\
PP2 & 0.874 & & & \\
PP3 & 0.902 & & & \\
\hline PS & & 0.560714 & 0.78 & 0.791544897 \\
PS1 & 0.771 & & & \\
PS2 & 0.814 & & & \\
PS3 & 0.652 & & & \\
\hline
\end{tabular}

\section{B. Model Fit}

SEM-AMOS version 22 was used to verify whether the proposed model fits the data. SEM was used because it is a second-generation version and provides graphs. Regarding the model fitness, [31] recommended three types of fitness: absolute fit, increment fit and parsimonious fit. All three fitness tests have their own indices. However, in this study one index was taken from each test to verify the proposed model.

To find the absolute fit index, the value of the root mean square error of approximation (RMSEA) was checked; for the increment fit purpose, the value of the comparative fit index (CFI) was checked; and for the parsimonious fit, the value of chi-sq/df was checked, as shown in Table 4. All these statistical indices suggest that the proposed model fits the data in this study.

TABLE III: DISCRIMINANT VALIDITY

\begin{tabular}{|c|c|c|c|c|c|c|c|c|}
\hline & AVE & $\mathrm{CH} 1$ & $\mathrm{CH} 2$ & $\mathrm{CH} 3$ & $\operatorname{ch} 4$ & CH5 & PP & PS \\
\hline $\mathrm{CH} 1$ & 0.61014 & 0.781114 & & & & & & \\
\hline $\mathrm{CH} 2$ & 0.666374 & 0.124609 & 0.816317 & & & & & \\
\hline $\mathrm{CH} 3$ & 0.647949 & 0.2704 & 0.126736 & 0.804952 & & & & \\
\hline $\mathrm{CH} 4$ & 0.795598 & 0.306916 & 0.131044 & 0.393129 & 0.891963 & & & \\
\hline CH5 & 0.661773 & 0.386884 & 0.1225 & 0.367236 & 0.450241 & 0.813494 & & \\
\hline PP & 0.710339 & 0.358801 & 0.112896 & 0.2916 & 0.2916 & 0.274576 & 0.842816 & \\
\hline PS & 0.560714 & 0.4225 & 0.222784 & 0.463761 & 0.389376 & 0.430336 & 0.855625 & 0.748808 \\
\hline
\end{tabular}

TABLE IV: MODEL FIT

\begin{tabular}{ccccccccc}
\hline & Absolute fit & & Incremental fit & & Parsimonious fit \\
\hline Fitness index & $\begin{array}{c}\text { Critical } \\
\text { value }\end{array}$ & $\begin{array}{c}\text { Test } \\
\text { value }\end{array}$ & $\begin{array}{c}\text { Fitness } \\
\text { index }\end{array}$ & Critical value & $\begin{array}{c}\text { Test } \\
\text { value }\end{array}$ & $\begin{array}{c}\text { Fitness } \\
\text { index }\end{array}$ & $\begin{array}{c}\text { Critical } \\
\text { value }\end{array}$ & $\begin{array}{c}\text { Test } \\
\text { value }\end{array}$ \\
\hline RMSEA & $<0.10$ & 0.078 & CFI & $>0.90$ & 0.91 & ChiSq/df & $<5$ \\
\hline
\end{tabular}

For the RMSEA, a value of 0 is interpreted as an exact fit; values less than .05 are a close fit; values between .05 and .08 are a fair fit; and values between .08 and .10 are a mediocre fit [33].

The chi-sq/df is 3.211, which is below 0.5; thus, the model fits. CFI is achieved, the score being 929.

C. Impact of Challenges on Project Success: The Mediating Role of Project Performance 


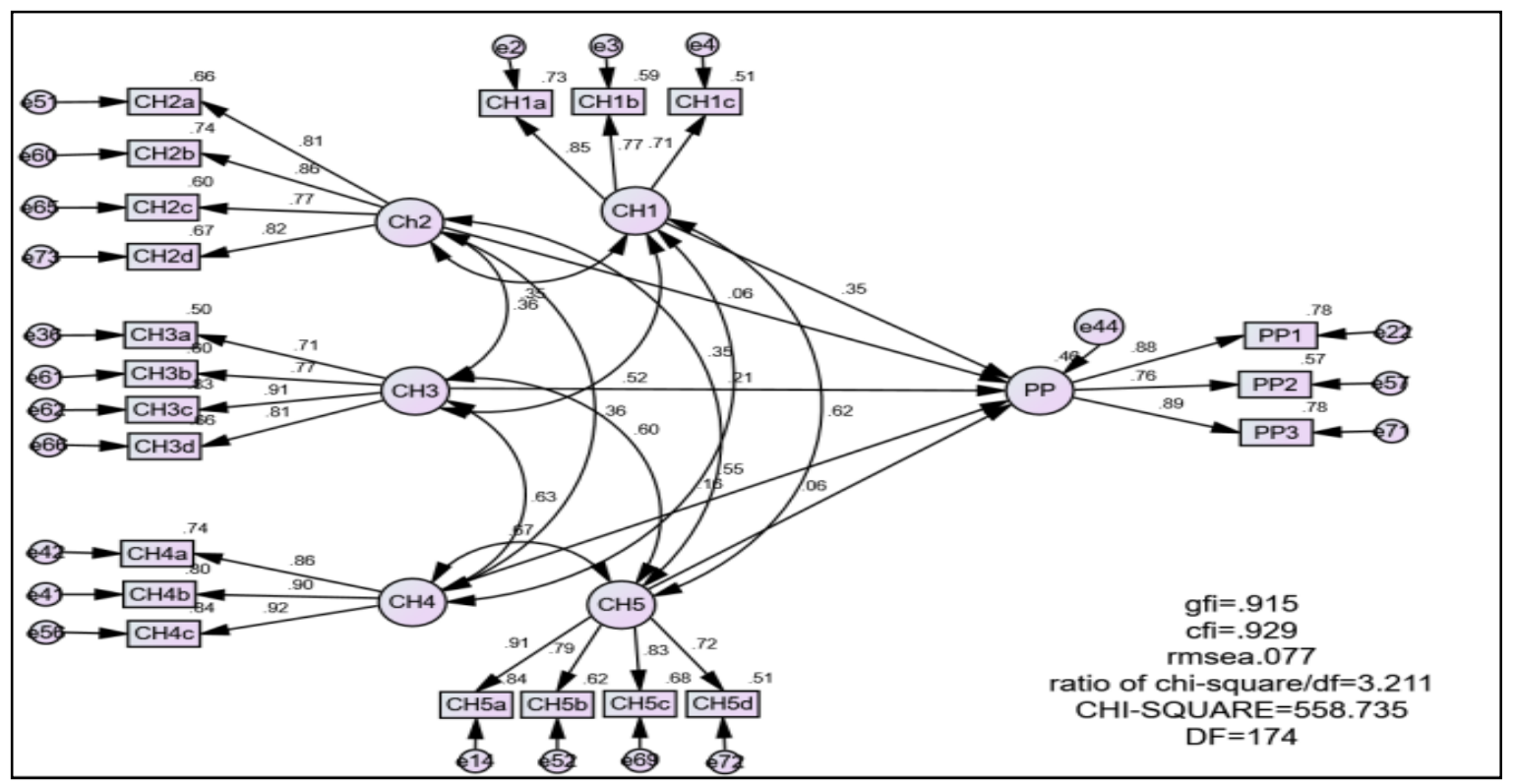

Fig. 2. The AMOS output showing regression (SEM) coefficient between the constructs (without mediator).

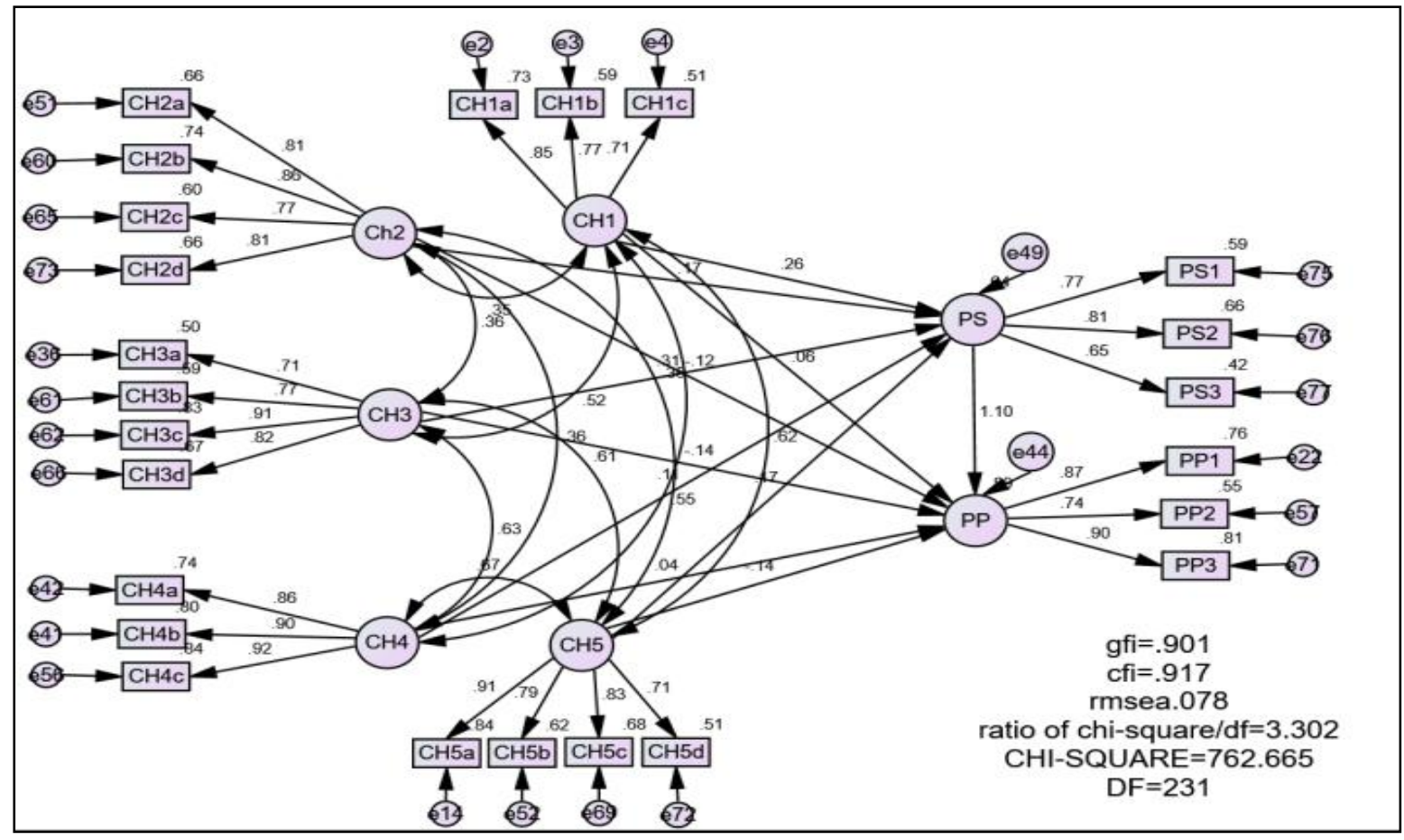

Fig. 3. The AMOS output showing regression (SEM) coefficient between the constructs (with mediator).

TABLE V: DIRECT AND INDIRECT EFFECTS OF CHALLENGES ON PROJECT SUCCESS

\begin{tabular}{|c|c|c|c|c|c|c|c|c|c|}
\hline IVs & $\begin{array}{l}\text { Direct without } \\
\text { Med }\end{array}$ & Sig. & IV to Med & Sig. & $\begin{array}{l}\text { Med to } \\
\text { DV }\end{array}$ & p-value & $\begin{array}{l}\text { Direct with } \\
\text { Med }\end{array}$ & $\mathrm{p}$-value & Results \\
\hline Challenge 1 & 0.34 & 0.00 & 0.061 & 0.34 & 1.10 & 0.00 & 0.26 & 0.00 & $\begin{array}{l}\text { Direct } \\
\text { Relationship }\end{array}$ \\
\hline Challenge 2 & 0.06 & 0.24 & -0.123 & 0.01 & 1.10 & 0.00 & 0.17 & 0.00 & $\begin{array}{l}\text { Indirect } \\
\text { relationship }\end{array}$ \\
\hline Challenge 3 & 0.20 & 0.00 & -0.143 & 0.03 & 1.10 & 0.00 & 0.31 & 0.00 & Partial mediation \\
\hline Challenge 4 & 0.16 & 0.02 & 0.044 & 0.47 & 1.10 & 0.00 & 0.11 & 0.11 & $\begin{array}{l}\text { Direct } \\
\text { Relationship }\end{array}$ \\
\hline Challenge 5 & 0.06 & 0.43 & -0.139 & 0.04 & 1.10 & 0.00 & 0.17 & 0.01 & $\begin{array}{l}\text { Indirect } \\
\text { relationship }\end{array}$ \\
\hline
\end{tabular}

Note: challenges are Higher costs, Technical difficulty, Risk due to different contract forms, Lengthy approval, Unfamiliarity with Green Technology.

To assess the hypothesized relationship, structural equation modelling (SEM) was performed. SEM is a multivariate technique to analyse complex models and explain multiple relations at a time [34]. In this study the relationship between dependent and independent variables was assessed. The variables were employed based on our 
conceptual framework. All the results from the mediation testing are shown in Table $\mathrm{V}$.

\section{DISCUSSION}

The results reveal that Challenge 2 and Challenge 5 are insignificant and have no impact on project success; thus, we reject our null hypotheses $2 \mathrm{a}$ and $5 \mathrm{a}$ with the p-value $<.05$. However, Challenges 1,3 and 5 are found to be predictors of project success with the p-value $<.05$. Consequently, we can interpret technical difficulty and unfamiliarity with green technology as not exerting an impact on project success. Project success has a lot to do with technical difficulty, and it depends on how complicated the technical procedures are. The results indicate that no significant impact of technical difficulty on project success is apparent in the particular context of the Chinese construction industry, so technical difficulty is not a relevant challenge affecting project success. Another particularly related challenge is familiarity with green technology, which is also not significantly related to project success. One of the valid reasons for this could be China's development in science and technology. Hence, project managers who are technically and technologically well qualified do not think that these challenges have any impact on project success.

To test the mediating effect of project performance between Challenges 1, 3 and 5 and project performance, the decision points from [31] are used. Table 4 reveals that Challenge 1 (higher cost) has an insignificant relationship with project performance; therefore, we can infer that there is a direct relation between higher cost and project success and that project performance has no significant mediating role between them. This result indicates that higher cost may have an impact on project success; however, the performance of the project has nothing to do with the higher cost.

Challenge 3 (risk due to different contract forms) has a significant relation with project performance, and project performance is a significant predictor of project success; thus, we can conclude that there is a partial mediation of project performance between risk due to different contract forms and project success.

Lengthy approval, which is Challenge 4 in our research, is found to have an insignificant impact on project success; thus, we can interpret lengthy approval as having a direct relation with project success and project performance as having no role between them.

Challenge 2 and Challenge 5 are initially found to be insignificant predictors of project success; however, they have a significant relation with project performance and project performance is a predictor of project success in both challenges. Therefore, we may summarize that there is somewhat indirect relationship between technical difficulty and unfamiliarity with green technology and project success.

\section{CONCLUSIONS}

This study aimed to examine the challenges that are usually faced by project managers during the management of green building construction projects and their impact on project success. Furthermore, the study intended to examine the mediating effect of project performance between the relationship of project management challenges related to green construction and their success. The study proposes some possible ideas to improve green construction project management. The previous literature suggested that there are five big challenges that project managers face: 1) increased cost; (2) lack of communication and interest; (3) high implementation cost; (4) lack of credible research; and (5) lack of interest from clients. The challenges were found to be predictors of project success except Challenges 2 and 5 . Thus, we can state that technical difficulty and unfamiliarity with green technology do not have an impact on project success. Project success is considerably related to technical difficulty and depends on how complicated the technical procedures are. The results indicate no significant impact of technical difficulty on project success, so it may be seen that, in the particular context of the Chinese construction industry, technical difficulty is not a relevant challenge that affects project success. Another particularly related challenge, familiarity with green technology, is also not significantly related to project success. One of the valid reasons for this could be China's development in science and technology. Hence, project managers who are technically and technologically well qualified do not think that these challenges have any impact on project success. The findings from this study suggest that competent project managers who are capable of overcoming the challenges may be especially helpful in ensuring the success of projects, ultimately adding value to the success of the construction industry.

\section{LIMITATIONS AND FUTURE AVENUES FOR RESEARCH}

Although the study aimed to achieve certain objectives, it is still limited to the conclusions that we may draw from it. The analyses were performed on a fairly small sample, so caution should be taken in generalizing the results. Moreover, the study did not take the experience of the respondents into consideration. The study is limited to the context of China, as the respondents were all from China. The study recommends future research areas, indicating the identifying characteristics that a project manager should have not only from the perspective of project managers but also from the perspective of other relevant parties. The study also recommends investigating ways to improve and strengthen the critical knowledge areas and capabilities explored in this research.

Further research can be performed using the characteristics of project managers and the challenges that may relate to the particular types of project managers. Moreover, the perspective of other stakeholders may be taken into account to draw an in-depth understanding of the phenomenon. We also recommend carrying out research regarding the awareness of project managers about the challenges and their remedy. This type of research may be helpful in identifying areas for improvement and later on will be helpful in improving the capabilities of project managers; ultimately, the probability of successful and better-performing green projects will be increased. 


\section{REFERENCES}

[1] Civil Exchange (CE). Submission on a proposal on the mandatory implementation of the building energy codes. [Online]. Available: http://www.civicexchange.org/eng/publication.aspx

[2] Environmental Bureau (EB). (2011). Policy and consultation papers: a proposal on the mandatory implementation of the building energy codes. [Online]. Available: http://www.enb.gov.hk/en/resources_publications/policy_consultation /building_energy_codes.html

[3] Q. K. Qian, E. H. Chan, and A. G. Khalid, "Challenges in delivering green building projects: Unearthing the transaction costs (TCs)," Sustainability, vol. 7, no. 4, pp. 3615-3636, 2015

[4] M. Hicks. United states, real estate, contract, project abandonment: separate legal concepts. [Online]. Available: http://www .mondaq.com/unitedstates/article.asp?articleid=60362

[5] DESA, "U. Population distribution, urbanization, internal migration and development: an international perspective," New York. 2011.

[6] W. Shen, "Preparing for China's" urban billion" policy implications and potential for international cooperation," Environmental Practice, vol. 15, no. 3,2013.

[7] BEE-U.S, 'China's Growing Green Building Industry and How U.S. Companies Can Get Involved', 2015.

[8] Z. Isik, D. Arditi, I. Dikmen, and M. T. Birgonul, "Impact of corporate strengths/weaknesses on project management competencies," International Journal of Project Management, vol. 27, no. 6, pp. 629-637, 2008

[9] J. S. Chou and J. G. Yang, "Project management knowledge and effects on construction project outcomes: an empirical study," Project Management Journal, vol. 43, no. 5, pp. 47-67, 2012.

[10] C. Hendrickson and T. Au, "Project management for construction: Fundamental concepts for owners, engineers, architects, and builders. Chris Hendrickson," 2008.

[11] I. Pant and B. Baroudi, "Project management education: The human skills imperative," International Journal of Project Management, vol. 26, no. 2, pp. 124-128, 2008.

[12] K. S. Sustainability, "A new element of project success from whose point of view is Velodrome park and wind turbine projects considered a success or failure?" University Library of Munich, Germany, 2014.

[13] B. G. Hwang and W. J. Ng, "Project management knowledge and skills for green construction: Overcoming challenges," International Journal of Project Management, vol. 31, no. 2, pp. 272-284, 2013

[14] F. T. Edum-Fotwe and R. McCaffer, "Developing project management competency: Perspectives from the construction industry," International Journal of Project Management, vol. 18, no. 1, pp. 111-124. 2000.

[15] Ministry of Construction PR China, Evaluation Standard for Green Building, Beijing: China Architecture and Building Press, 2006

[16] T. E. Glavinich, Contractor's Guide to Green Building Construction, New Jersey: John Wiley \& Sons. 2008

[17] International Initiative for Sustainable Built Environment (iiSBE). (2005). The integrated design process. [Online]. Available: from http://www.iisbe.org/down/gbc2005/Other_presentations/IDP_overvi ew.pdf

[18] B. G. Hwang and J. S. Tan, "Sustainable project management for green construction: Challenges, impact and solutions," in Proc. Ciob World Construction Conference, 2012.

[19] C. J. Kibert, Sustainable Construction: Green Building Design and Delivery, New Jersey: John Wiley \& Sons, 2008.

[20] E. Tagaza and J. L. Wilson, Green Buildings: Drivers and Barriers E Lessons Learned from Five Melbourne Developments, Melbourne, Australia: University of Melbourne and Business Outlook and Evaluation, 2004.
[21] X. L. Zhang, L. Y. Shen, and Y. Z. Wu, "Green strategy for gaining competitive advantage in housing development: A China study," Journal of Cleaner Production, vol. 19, no. 1, pp. 157-167, 2011, 2011.

[22] B. G. Hwang and J. S. Tan, "Green building project management: Obstacles and solutions for sustainable development," Sustainable Development, 2010.

[23] J. U. Ling, "The project manager's personal characteristic, skills and roles in local construction industry," Faculty of Civil Engineering, University Technology Malaysia, 2003.

[24] D. Eisenberg, R. Done, and L. Ishida. Breaking down the barriers: Challenges and solutions to code approval of green building. Research report by the Development Center for Appropriate Technology. [Online]. Available: http://www.mrsc.org/artdocmisc/breaking_down_barriers.pdf

[25] Y. H. Ahn and A. R. Pearce, "Green construction: Contractor experiences, expectations, and perceptions," Journal of Green Building: Summer, 2007.

[26] B.-G. Hwang, S. R. Thomas, and C. H. Caldas, "Performance metric development for pharmaceutical construction projects," Intrnational Journal of Project Management, vol. 28, no. 3, pp. 265-274

[27] B.-G. Hwang, S. R. Thomas, and C. H. Caldas, "Application of customized industry-specific metrics to assessment of capital projects performances," KSCE Journal of Civil Engineering, 2011.

[28] K. Cho, T. Hong, and C. Hyun, "Effect of project characteristics on project performance in construction projects based on structural equation model," Expert Systems with Applications, vol. 36, no. 7, pp. 10461-10470, 2009.

[29] D. K. Ahadzie, D. G. Proverbs, and P. O. Olomolaiye, "Critical success criteria for mass house building projects in developing countries," International Journal of Project Management, vol. 26, no. 6, pp. 675-687, 2008.

[30] S. W. Hughes, D. D. Tippett, and W. K. Thomas, "Measuring project success in the construction industry," Engineering Management Journal, vol. 16, no. 3, pp. 31-37, 2004.

[31] J. F. Hair, W. C. Black, B. J. Babin, R. E. Anderson, and R. L. Tatham, Análise multivariada de dados. Bookman Editora, 2009.

[32] L. J. Cronbach, Coefficient Alpha and the Internal Structure of Tests, 1951.

[33] F. Chan, G. K. Lee, E. J. Lee, C. Kubota, and C. A. Allen, "Structural equation modeling in rehabilitation counseling research," Rehabilitation Counseling Bulletin, vol. 51, no. 1, pp. 44-57, 2007

[34] D. Kaplan, Structural equation modeling. Foundation and Extensions, 2000

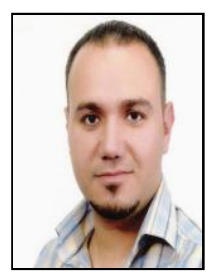

Mohammed Shareef M. S. Hasan was born in Iraq in 1977. He received the higher diploma in building and construction engineering in 2001 from the University of Technology , Baghdad, Iraq. Since 2002, he has been with General Directorate of Northern Electricity Production, Ministry of Electricity, Iraq. He received his master's degree in construction engineering and management in 2013 from SHIATS, Allahabad, India. $\mathrm{He}$ is pursuing his $\mathrm{PhD}$ study in construction management at School of Civil Engineering and Mechanics, Huazhong University of Science and Technology, Wuhan 430074, Hubei, China. 